\title{
Joint Venture Manufacturing in China: an Exploratory Investigation
}

\author{
Zhang Lihong and Keith Goffin
}

Tsinghua University, China and Cranfield School of Management, UK

\begin{abstract}
AUTOBIOGRAPHICAL NOTES
Zhang Lihong is a PhD student from Tsinghua University in Beijing who has spent the last two years on a research scholarship at Cranfield School of Management studying international joint venture manufacturing in China. He has published a number of articles in Chinese journals and three books.

Keith Goffin is a Senior Lecturer in Operations Management who joined Cranfield School of Management in 1995, after a successful career in the medical electronics industry. His research interests are innovation, new product development and supplier management and he has published in a number of international journals.
\end{abstract}

\section{CONTACT ADDRESS}

Cranfield School of Management, Cranfield, Bedford MK43 OAL, England, UK

Tel: 0044-(0)-1234-751122; Fax: 0044-(0)-1234-751806

email address: k.goffin@Cranfield.ac.uk 


\title{
Joint Venture Manufacturing in China: an Exploratory Investigation

\author{
Zhang Lihong and Keith Goffin
}

\author{
Tsinghua University, China and Cranfield School of Management, UK
}

\begin{abstract}
International joint venture (IJV) manufacturing is important for both the Chinese economy and a large number of foreign investors. A review of the literature from both Western and Chinese researchers showed that although the purpose and advantages of IJV manufacturing in China are known, a vital aspect—operations management-has largely been ignored. Therefore, exploratory interviews with managers at six companies were conducted to investigate the operations management issues faced by IJV manufacturers in China. Four main problems were identified: the difficulty with recruiting and training suitable employees; all aspects of supplier management; problems with achieving high-quality output; and achieving an effective IJV business culture. The results have implications for not only researchers, in that they indicate where more research is necessary, but also for practitioners, since they identify the areas where IJV manufacturers are most likely to encounter problems in China.
\end{abstract}

\section{$\underline{\text { KEYWORDS }}$}

International joint ventures; Manufacturing in China

\section{ACKNOWLEDGEMENT}

The authors acknowledge the support of the Sino-British Friendship Scholarship Scheme in funding one year of Zhang Lihong's research scholarship at Cranfield, during which some of the research described in this paper was conducted. 


\section{INTRODUCTION}

Two important aspects of foreign direct investment (FDI) in the Chinese economy can be identified. Firstly, international joint ventures (IJVs) account for over half of FDI (Anonymous, 1996a) and, secondly, the majority of IJVs are manufacturing companies (Schroath et al, 1993). As a consequence, more than 10 million Chinese are employed in manufacturing IJVs and over 50\% of manufactured goods exported from China in 1994 came from such companies (Anonymous, 1996a). Manufacturing IJVs are viewed by the Chinese authorities as the preferable form of foreign investment because they provide an opportunity for the transfer of advanced technology and management skills to the Chinese economy and lead to increased exports (Anonymous, 1996b). Foreign companies have a particular interest in manufacturing in China, as it gives them access to the large Chinese market and to potentially low production costs (Davies, 1994). Consequently, for example, more than one hundred of the Fortune 500 companies have businesses in China (Lu and Wang, 1996) and many other companies have also invested. Since IJV manufacturing is critical to both the Chinese economy and many foreign investors, it is an area worthy of investigation by operations management researchers.

Investments in IJV manufacturing are often thought worthwhile because of the strategic benefits they can bring to both local and foreign partners. Currently, most IJVs are located in specific areas-along the coast or in cities such as Beijing and Shanghai (Lu, 1997) — and the main industries represented are engineering, electronics, chemicals and plastics (Pan, 1994; Yan and Gray, 1994). Glaister and Wang (1993) showed that IJVs tend either to be small companies interested in exporting from China, or large multi-national companies focusing more on the Chinese domestic market. Despite their apparent advantages, IJVs in China are not always successful and parent companies are often 
dissatisfied with IJV performance (Beamish, 1993). In addition, it has been identified that poor financial performance is often related to operational problems (Anonymous, 1996a; Anonymous, 1995; Han and Xu, 1995).

The importance of research into operations management in an international context has been recognised (Sweeney, 1994; Adam and Swamidass, 1992). Similarly the importance of research into IJVs world-wide (Fey, 1994) and especially in China (Anonymous, 1996a and 1996b) has been noted. A stream of research has investigated the role, the relevant legislation, the strategic planning, and the organisation of IJVs in China (see for instance: Friedman and Kalmonoff, 1961; Hennart, 1988 and 1991; Fey, 1994; Chi and McGuire, 1996; Mitchell and Singh, 1996; Harrigan, 1986; Hamel, 1991; Janger, 1980; Killing, 1983). However, both foreign and Chinese researchers have largely ignored the operations management issues faced by IJV manufacturers in China. Consequently, this paper aims to:

1) Review the literature on IJVs, by both Western and Chinese researchers, to give the full background on the need for operations management research;

2) Report the results of an exploratory investigation of operations management in SinoForeign manufacturing;

3) Identify the most relevant opportunities for future research into manufacturing IJVs in China.

\section{INTERNATIONAL JOINT VENTURES}

Most of the literature states that IJVs are a key form of international business (see, for example Harrigan, 1986; Fey, 1994; Han and Xu, 1995). The main rationale for using IJVs over other forms of FDI is that they normally have lower transaction costs and offer strategic or specific local business advantages (Baran et al, 1996). For example, IJVs enable their parent companies to share the risks in industries where high capital investments are 
necessary (Hennart, 1988). Another example where IJVs offer a big advantage is in the potential transfer of knowledge, such as production "know-how" and management skills (ibid). The perceived main advantage of IJVs for foreign companies is the access it gives them to the Chinese domestic market (Davies, 1994).

Despite their potential benefits, IJVs can be difficult to manage. Problems which may be encountered include: 1) conflicts on the sovereignty of technology transfer between partners or between partners and the host government; 2) a loss of competitive advantage which may result if the decision making process between the IJV partners is slow; and 3) the relative inexperience of managers in running IJVs (Harrigan, 1986). Since the "academic understanding of joint ventures is still limited in scope and depth" (Yan and Gray, 1994), it has been recognised that research needs to be done at operational level to provide companies with clear information on how to manage their ventures successfully (Baran et al, 1996).

\section{$\underline{\text { Research into IJVs in China }}$}

Research into IJVs in China has been published in both the English and Chinese languages, by both foreign and Chinese researchers. A previous survey of the literature identified over 70 papers relevant to IJV manufacturing in China (Zhang and Goffin, 1998). A classification of the English-language articles showed that the majority of these have been published in general management journals, followed by marketing and human resource management journals. Marketing, strategic planning, and IJV performance are the topics most frequently discussed. Although operational issues are frequently mentioned-because management researchers nearly always choose to study manufacturing IJVs in their empirical studies - these are not investigated in detail, or from an operations perspective. 
A classification of the literature published in Chinese, showed that Chinese researchers have, similar to their foreign counterparts, investigated legislation on IJVs (e.g. Rong and Wei, 1994); the problems and risks of forming IJVs (e.g. Anonymous, 1996a and 1996b); and IJV performance (e.g. Chen 1995; Rong and Wei, 1994). In addition, Chinese researchers have highlighted the importance of investigating the real value of IJVs to the Chinese economy, whilst foreign researchers appear more interested in how an appropriate partner can be selected and an IJV can be successfully launched.

Although the literature on IJVs, including those in China, is broad, three key areas can be identified:-

- The Chinese business environment and its influence over IJVs;

- Operational issues and problems in manufacturing ventures;

- Evaluating the performance of IJVs.

\section{The Business Environment}

The complex and dynamic business environment in China makes the management of IJVs an intricate task (Bruijn and Jia, 1993). For example, although an IJV is recognised as an international alliance under Chinese law (Teagarden and Glinow, 1990), regulations governing IJVs are not totally clear and regional areas do not always follow the laws passed by central government (Chen, 1995). In addition, bureaucratic obstacles resulting from the various authorities are not unusual and they complicate, for example, both the formation of IJVs and the co-ordination with local suppliers (Pan et al, 1995). State-owned Chinese enterprises are encouraged to form IJVs with foreign partners, while private enterprises are not allowed (Rong and Wei, 1994). However, state-owned enterprises are recognised as having serious limitations as IJV partners, including being slow and ineffective at decision 
making, having too many employees and possessing too much obsolete manufacturing equipment. Because IJVs bring together employees from different cultural backgrounds, this can also be problematic (Fan, 1996; Teagarden and Glinow, 1990; Anonymous, 1996c).

The above factors make the formation of IJVs difficult (Pan et al, 1995) and only about $60 \%$ of manufacturing IJVs achieve full implementation i.e. successfully manufacture products (Anonymous, 1996a). To create a successful IJV, a number of steps are required: suitable partners must be found (Glaister and Wang, 1993; Lu and Wang, 1996); clear business objectives must be set at both strategic and operational levels (Campbell, 1989; Teagarden and Glinow, 1990); and a range of relationships must be formed. Developing and maintaining relationships, both internally and externally to the IJV, are vital to its success (Campbell, 1989; Martinsons and Tseng, 1995a). The Chinese word guangxi-which means personal contacts-is often mentioned in the literature (e.g. Luo, 1995; Martinsons and Tseng, 1995a and 1995b) and so it is essential for IJVs to develop good working relationships with all of their contacts (Chan, 1996; Pan, 1994; Martinsons and Tseng, 1995a and 1995b).

\section{$\underline{\text { Operational Issues }}$}

A number of operational problems associated with IJVs in China can be identified from looking at both the trade and research literature. In the trade and popular management press operational issues are frequently mentioned, such as difficulties with: quality control (e.g. Anonymous, 1996c); production capacity (e.g. Lerner, 1996); and supplier management (e.g. Anonymous, 1993).

In the research literature some additional points have also been raised but not systematically investigated. For example, recruiting suitable staff for IJV manufacturing is difficult. The shortage of skilled operators and managers and the large differences between 
the Chinese and the foreign approaches to management make recruitment and training inevitably difficult (Tsang, 1994). Finding skilled Chinese managers is particularly difficult (Pan et al, 1995). Local employees often have not had suitable training and so this influences the level of technology which can be used in manufacturing in China (Pan et al, 1995). Other human resource management issues such as employee discipline and trade union relations may also pose serious problems to operations if they are not correctly handled (Tsang, 1994).

Quality control strongly influences the success of manufacturing IJVs in China (Tsang, 1995; Martinsons and Tseng, 1995a and 1995b; Chua and Kin-Man, 1993). Although the concept of total quality management has been emphasised in China for the past decade, effective quality systems have seldom been achieved and the standard of manufactured goods and components is often variable (Martinsons and Tseng, 1995b). The lack of high-quality local suppliers has led many joint ventures to extend their own quality control and training programmes to include their Chinese suppliers (ibid).

The relationships with suppliers are a complex and crucial part of IJV manufacturing management (Martinsons and Tseng, 1995a and 1995b; Tsang, 1995). One team of researchers concluded that "sourcing of materials and components is a serious issue for IJVs in China" (Pan et al, 1995) and the Chinese authorities often exert pressure on companies to purchase from specific suppliers. However, because of the quality problems with local suppliers, many IJVs source a high proportion of their materials overseas—often a larger percentage than initially projected. This can lead to higher-than-expected production costs and to difficulties with the balance of foreign exchange which is required of IJVs (Campbell, 1989). 
The process and speed of technology transfer within IJVs is a critical strategic issue (Lan, 1996; Tsang, 1995; Martinsons and Tseng, 1995a; Anonymous, 1995). Major problems which hinder the smooth implementation of technology transfer have been identified as the recruitment of suitable staff and managers, communication and training (Tsang, 1995).

The complexity of manufacturing management has been acknowledged by Chinese researchers ( $\mathrm{Lu}$ and Wang, 1996), as is the need for more Chinese managers to gain experience in this area (Wang, 1996). For example, Chinese managers are often not very good at identifying the causes of operational problems and developing appropriate solutions (Han and $\mathrm{Xu}, 1995$ ). Although it is recognised that Chinese managers need to learn general management concepts and principles, "what is more important [to Chinese industry] is the value of concrete operations management skills" (Lu, 1996).

\section{Performance Evaluation}

The importance and proliferation of IJVs in China has drawn the attention of academic researchers but "little is known about the performance of these ventures, nor the factors that affect the outcomes" (Osland and Cavusgil, 1996). Some studies (e.g. Chen, 1995) noted that joint ventures with Western firms generally have a better reputation and perform well, whilst small joint ventures with Hong Kong and Taiwanese firms often lead to more problems, such as limited technology transfer and illegal business practices. Other research has identified that sharing the management control of IJVs between partners leads to more satisfactory business performance (Beamish, 1993; Lu and Wang, 1996). It has also been identified that poor operations management is a cause of inferior financial performance (Anonymous, 1995; Han and $\mathrm{Xu}, 1995)$. However, previous studies have not investigated quantitative measures of manufacturing performance such as cost, labour productivity and quality. 
Partners sometimes have different views on how successful their IJVs are, because they use different criteria to evaluate performance (Luo, 1995). For example, Chinese partners tend to focus on long-term issues such as technology transfer, managerial learning and exports. In contrast, foreign partners use criteria such as profitability and market share (Yan and Gray, 1994). Beamish (1993) has pointed to the need for research on how partners reach agreement on common measurements for IJV performance, and on how manufacturing performance is best measured and improved.

\section{$\underline{\text { Summary }}$}

Three points can be concluded from the literature review: 1) The business environment makes manufacturing in China difficult; 2) Operations issues have been identified but not investigated directly (e.g. no previous survey has been made of the problems facing operations managers); 3) Business performance is increasingly being discussed, but the influence of manufacturing on this has, to date, largely been ignored. Therefore, empirical research is necessary to provide both practitioners and researchers with clear information on IJV operations issues.

\section{RESEARCH DESIGN}

The aim of the empirical part of this study was to make an exploratory investigation of operations management issues at IJV manufacturers. To achieve this, in-depth interviewing of operations managers was chosen as the most appropriate methodology. Lists of IJVs in China were obtained by visiting the Foreign Trade Departments in Beijing, Hunan and Shanghai, who provided details of over 1000 companies. From these, a sample of 36 manufacturing companies were selected randomly-this sample included a mixture of industries and a range of different foreign IJV partners-and contacted to see if they would 
allow access for research purposes. From these, 19 agreed to co-operate with a larger, ongoing study of IJVs. Purposive sampling-based on the objectives of the research and accessibility of companies - was used to choose six of the 19 as the exploratory sample. The exploratory sample was selected to include companies which had been formed at least three years ago; a mixture of foreign partners; different sizes of plants (typically $\$ 20$ million investment or more); and a range of industries. All six companies had state-owned Chinese IJV partners because, as mentioned in the literature, only public companies in China may form IJVs with foreign partners.

A semi-structured questionnaire was developed for the interviews. This was based on ideas from the literature and covered several areas: problems of IJV manufacturing; relationships between IJV partners; supplier management; quality management; and manufacturing performance measures. To ensure that the questions were easy to understand and relevant to IJV managers, the questionnaire was tested in a pilot interview. It should be noted that openended questions were mainly used and, in order to obtain an unbiased view of the issues in IJV manufacturing in China, respondents were first asked questions such as:

- What were the main problems in setting up IJV manufacturing operations?

These were followed by more specific questions, which checked whether problems mentioned in the literature were encountered, such as supplier or quality management. (A copy of the six page questionnaire is available from the authors on request.)

The primary interviewees were managers with experience of managing IJV manufacturing in China-three were Chinese and three were expatriates managing operations in China (two of the latter were interviewed in the UK). Interviewees were encouraged to talk openly by the assurance of anonymity (an important point for this type of fieldwork in China) and the interviews typically lasted one hour. During each interview detailed notes were taken and, if the interviewee agreed, tape recordings were made to enable 
the use of direct quotes in the data presentation. In two cases, short secondary discussions were possible with other managers (e.g. the Personnel Manager at one company) and, in one case, telephone contact was made with the company post-interview, to clarify certain points in the data.

Following recommendations in the case study literature (e.g. Miles and Huberman, 1994), the analysis consisted of three main stages; data reduction; data display (within-case analysis; and cross-case analysis); and drawing conclusions. To ensure the robustness of the analysis, data reduction was performed by both researchers independently inspecting the interviews notes and transcripts.

\section{RESULTS AND CROSS-CASE ANALYSIS}

Table I gives the background information on the six manufacturing IJVs studied and summarises the cross-case analysis. It can be seen that a range of industries are represented, including chemicals, car components, and electronics. The companies have been disguised and will be referred to as Coating-Co (a manufacturer of protective coatings), Brake-Co (car brakes), Digi-Switch-Co (digital switches), Boiler-Co (steam boilers), Motor-Co (motorcycles) and Fridge-Co (domestic refrigerators). The IJVs have partners from various foreign countries and their manufacturing facilities are in three different parts of China; the coastal area, metropolitan Beijing, and inland. Four of the companies make-to-stock, whereas Digi-Switch-Co assembly-to-order and Boiler-Co make-to-order. Most companies use MRPII for their production planning and control, although full project management techniques were used at Boiler-Co to plan their make-to-order production. Interestingly, only four of the plants studied were making profits at the time of the investigation-Fridge-Co had "passed the worst point" (interviewee's comment) and started to reduce their financial losses, 
whereas full production at Brake-Co had been delayed because of problems in manufacturing.

\section{INSERT TABLE I}

A wide variety of problems in managing operations in Chinese IJVs were identified by respondents. However, cross-case analysis produced the following classification of main areas:

- Recruitment and training;

- Supplier management;

- Quality management;

- Achieving an effective IJV business culture

- Other operations issues.

\section{$\underline{\text { Recruitment and Training }}$}

All six interviews showed that the recruitment and training of IJV staff is an important factor for the success of manufacturing operations. For example, Fridge-Co identified it as their main problem and Brake-Co said that their second main issue is recruitment of good people (supplier management was their first).

Digi-Switch-Co had found it hard to recruit the right sort of employees and Brake-Co had even had to build company houses to attract good people. Although Fridge-Co had expatriates in charge of nearly every department, manufacturing operations were still not working to their satisfaction-the most serious problems for them were the lack of competent people at the middle management level and the low levels of competence of many of their operators. Since many people in China "were not properly educated, ... it takes lots of 
time and patience to get them [employees] to understand why we want to do something in a certain way" (Coating-Co). To tackle these sorts of problems, Motor-Co had developed a comprehensive programme of both on-the-job and off-the-job training for all of its employees. In addition, Motor-Co sent over 200 employees on visits to their partner's plants in Japan, to gain manufacturing experience.

From discussions with the interviewees, three main causes of the recruitment and training problems could be identified:

- The majority of new IJVs are required to take employees from their Chinese partner's operations.

- The lack of adequately trained staff in China, exacerbated by the tendency of new IJVs to try and hire experienced staff from established ventures

- Work-force mobility is seriously restricted by the requirements of the Chinese authorities for employees to register their place of residence.

\section{$\underline{\text { Supplier Management }}$}

Supplier management is a key issue for all six companies in the exploratory sample-for example Brake-Co said "by far and away the biggest issue for us is working with our suppliers". The six companies all have strict procedures for selecting and managing suppliers - these procedures have nearly always been directly adopted from the foreign IJV partner's practices. For example, Motor-Co have categorised their relationships with suppliers into three levels by volume, following the guidelines of their Japanese partner. In choosing their suppliers, all sample companies put most emphasis on quality, followed by delivery performance and thirdly, price. 
All six case companies have tried to work with local suppliers, because they normally have lower prices and because their proximity should enable more flexible delivery. However, problems were often encountered with local suppliers and the main ones cited were delivery performance and variable quality. Local suppliers "do not always deliver what they promise" (Fridge-Co); they "don't know simple things like statistical process control, ... and they don't have traceability" (Brake-Co); and "they really have no concept of what an automotive supply base has to deliver" (Brake-Co). Both quality and delivery performance are likely to cause problems if local suppliers are not carefully monitored and therefore purchasing managers constantly "have to keep [themselves] well-informed in order to manage the supply base" (Digi-Switch-Co).

Due to the severity of the problems with local suppliers, it is an issue that can take a long time to solve. Boiler-Co said that they have had to put a lot of time and resources into training and maintaining their supplier base whereas Fridge-Co have invested in helping one of their suppliers to set up production on their own site. Since the IJV was launched in 1994, Brake-Co had worked to improve their supplier base but "the development of suppliers is going to be a long ongoing thing”. Only one company, Digi-Switch-Co had progressed far enough with their suppliers to have started to ask them to contribute to product innovation. (Note that Digi-Switch-Co was founded in 1988 - the second oldest IJV studied-and therefore had worked a long time with their suppliers.)

\section{Quality Management}

Quality management is a crucial factor for all the companies. Motor-Co achieved significant sales growth during a period of stable demand for motorbikes because of their "superior brand and excellent quality image in the customer's eyes". In contrast, Fridge-Co's Chinese partner lost their number three market position in China "mainly due to our product quality 
problems and backward after-sales service" and similar problems had been encountered in the IJV. Boiler-Co, Motor-Co and Digi-Switch-Co all spoke of their strict quality inspection procedures for incoming goods (from suppliers) and for the various stages of production within their IJVs.

Quality training programs are run at all the sample companies on a semi-regular basis, to emphasise its continuing importance. As mentioned in the earlier section on training, some companies have gone to great lengths to train their staff, in particular MotorCo sent many of their people to Japan, and used these visits to give them quality training. At Coating-Co the source of many quality problems was seen to be the attitude of the employees because, "they're too ready to compromise when the thing doesn't come out right".

\section{$\underline{\text { Achieving an Effective IJV Business Culture }}$}

All of the IJVs reported significant problems in achieving an effective business culture. The interviewees identified four inter-related problems: the acceptance of foreign management practices; the attitudes of employees; achieving teamwork between different departments; and managing change.

Foreign IJV partners find that operating in China means that management practices that they have previously taken for granted need to be established. The manager from Coating-Co spoke of his frustration on this point and said "a big problem with Chinese partners is their lack of understanding of how modern businesses work". He continued and explained how moves to install a computer system to track manufacturing performance had been strongly resisted, because this made information readily available which had previously been controlled by department managers. All of the other companies had also experienced problems having management practices adopted and in creating an effective company culture. For example, the Chinese manager at Digi-Switch-Co said that although many of his 
Chinese colleagues had agreed to follow the Western management approaches introduced by the German partner, there had still been much opposition from employees. At Boiler-Co the operations manager thought that technical issues were comparatively easy to communicate, whereas anything to do with why operations should be managed in a particular way was always difficult-for instance, the introduction of a database of the manufacturing performance of individual departments was strongly resisted by the work-force.

Despite efforts to recruit good people, all of the IJVs had problems with their employees. The Swedish manager at Fridge-Co complained at what he saw was a lack of initiative amongst many of his people and the need to tell them exactly what they needed to do. Local people, particularly the older generation who are often in management positions, have problems in understanding and absorbing foreign management ideas, such as the need for clear performance measures. This can lead to disagreements and had led to "a feeling of 'them and us' " at Coating-Co. IJV partners may have different opinions on suitable candidates for management positions-for example, this led to a significant dispute over the appointment of the manufacturing manager at Boiler-Co.

Five out of the six IJVs have had problems co-ordinating different departments. Fridge-Co have a long supply chain within the company and the operations director had spent much of his time co-ordinating the work of different departments because "they do not work as a team". As a consequence of poor teamwork, the cost of manufacturing at FridgeCo was " $20 \%$ higher than it should be" (benchmarked against the foreign partner's plant). Boiler-Co had implemented project management techniques to improve the co-operation between functional areas but so far had not been able to achieve one of the goals of better coordination - to satisfy their customers' delivery requirements. Motor-Co have had frequent conflicts between manufacturing and marketing which have hampered the implementation of JIT and caused problems in attempts to rationalise the product range. 
The attitudes of employees, their resistance to the introduction of management techniques and the lack of teamwork between departments are all related and are something that IJV managers need to change in order to create an effective IJV business culture. However, change was perceived as difficult to manage, requiring time and foreign managers needed to "be patient [in] understanding the country, the people and the culture" (Brake-Co). In order to effect change, Motor-Co sent 200 employees to Japan and, according to their Chinese General Manager, used these visits to influence their "people's minds and their way of thinking". Several of the interviewees said that they thought it was essential for foreign and Chinese managers to have both cultural understanding and appropriate language skills to be successful at managing IJVs in China.

The discussions with operations managers on the issue of achieving the right IJV culture identified the severe problems. They also indicate the range of skills necessary for operations managers in IJVs in China and demonstrate the delicate balance required-to ensure that good performance is achieved, foreign management methods probably need to be adapted, rather than simply adopted.

\section{$\underline{\text { Other Operations Issues }}$}

In addition to problems in the four areas above, a number of other issues were identified by the interviewees. Coating-Co mentioned the problems they had in finding the right IJV partners when they started in 1990 and in building a major chemical works they also had severe problems in ensuring that the stringent safety guidelines of the UK partner were met. At Boiler-Co, production of large industrial steam boilers took longer and was more expensive than at the US partner, with the result that the IJV was having cash-flow problems (70\% of the cost of their products is supplier parts and customers pay only $10 \%$ of the price in advance). 
At the two companies which were not profitable (at the time of the research), severe problems were mentioned-as might be expected. Brake-Co had suffered from very late deliveries of the plant equipment ordered in 1994 in China, and this was one of many factors which had delayed full production. Fridge-Co were currently still struggling to reduce their costs to a competitive level and also saw the need to develop new products which fit the Chinese market better. The Personnel Manager of Fridge-Co was very critical and summarised their problems as: "we have a first class facility; a second class work-force; third class management; and a forth class product".

\section{CONCLUSIONS}

The large number of papers published shows that IJVs in China are attracting the attention of management researchers. It is somewhat ironic, however, that although most IJVs in China are manufacturing companies, operations management issues have largely been ignored. The importance of IJVs to China and to foreign companies is clear and therefore their performance needs to be studied from not only the marketing and strategic perspectives. Operations management research is important "in order to reveal the myth around how a JV in China is actually managed and evolved, and what are the key success factors [sic]" (Fan, 1996).

The findings show that, although IJV manufacturing potentially has significant advantages for partners, companies typically face many operational problems in the Chinese business environment. Although articles in the extant literature have produced evidence of the various operations management issues which play a role, no previous research has shown the extent to which individual companies are likely to encounter these issues. The research confirms points identified in the literature such as the importance of recruitment and training; quality and supplier base management but, in addition, highlights how the achievement of 
successful IJV manufacturing is dependent on accomplishing an effective IJV business culture. It also indicates how operations managers working in Sino-Foreign IJVs need to be capable of managing in a complex cross-cultural environment.

The research has, in common with many exploratory investigations, some methodological limitations which will need to be addressed in subsequent studies. These include the small sample of six companies which, although covered a range of industries, may not be representative of IJV manufacturing in China as a whole. At each company only one manager was interviewed at length; further studies should attempt to talk to several managers at each venture and triangulate between these data sources. (However, it should be noted that obtaining access to several managers at one company can be difficult. In their wider study of IJVs, the authors have noted that Chinese operations managers will normally not allow researchers to talk to their staff on a first visit.) The six companies studied were all formed at least three years ago and therefore may show some survivor bias. However, as the focus of this study was not the type of operational problems that lead to IJV closure, this is an acceptable limitation. Longitudinal studies of the problems facing IJVs and the ways they solve them is a much needed approach. In addition, Chinese and foreign attitudes towards management can be very different and perceptions of operational problems may differ between these two groups. In this exploratory study, however, no attempt was made to understand whether the different partners held different views.

Although the small sample of managers interviewed limits the external validity of the findings, the results do provide a clear indication of the need for further research. Many questions need investigation and they should be answered by suitable empirical research made from an operations management perspective. Key areas where future research is needed are:- 
- Quality Management. A study of quality management in IJVs is needed to determine how they achieve improvements over time and how quickly quality levels reach those achieved by foreign partners' plants producing similar products.

- Supplier Management. Research is necessary to identify best practices in supplier management; how many of these have been adopted from foreign IJV partners' practices; and how the percentage of local sourcing changes over time.

- Cross-cultural research. To better understand the problems operating managers face in creating the right business culture in their manufacturing operations. How is this problem most effectively addressed?

- Manufacturing Strategy. Partners in manufacturing IJVs often have different objectives. How are these differences resolved and how does this lead to the formulation of a manufacturing strategy? This is an area where little previous research has been conducted.

The current research clearly shows that operations managers in manufacturing IJVs in China face a number of difficult challenges. If the results are representative of the Chinese IJV manufacturing sector as a whole, then foreign companies face a difficult task in achieving their goals and so it is not surprising that many joint ventures are not successful. Achieving successful IJV manufacturing takes skill, time and patience because, as one respondent said, "people in a hurry in China don't succeed". 


\section{REFERENCES}

Readers should note that some confusion can arise in referencing Chinese publications. This is because the Chinese write their family name first, followed by their given name. Therefore, some Western researchers make mistakes in shortening references to surnames and initials. In the following list of references, Chinese surnames are given with initials and, for example the first author's name is Zhang Lihong and this is correctly shortened to Zhang, L.

1. Adam, E. E. Jr and Swamidass, P. M. (1992), "Assessing operations management from a strategic perspective", in Voss, C. A. (Ed.), Manufacturing Strategy - Process and Content, Chapman and Hall, London, pp. 373-401.

2. Anonymous, (1993) "Sourcing goods and parts: networking", Business China, Vol. 19 No. 7, April 5th, pp. 3-4.

3. Anonymous (1995), "Status, problems and suggestions for China in attracting foreign direct investment" (in Chinese), Journal of Industrial Economy of China, No. 10, pp. 5358.

4. Anonymous (1996a), "A Study of the usage of foreign direct investment (the first part)" (in Chinese), Management World, No. 2, pp. 46-54.

5. Anonymous (1996b), "A Study of the usage of foreign direct investment (the second part" (in Chinese), Management World, No. 3, pp. 79-90.

6. Anonymous (1996c), "Saving face, improving quality", Business Asia, Vol. 22 No. 17, August 19th, pp. 12.

7. Baran, R., Pan, Y. and Kaynak, E. (1996), "Research on international joint ventures in East Asia: A critical review and future directions", Journal of Euromarketing, Vol. 4 No. 3-4, pp. 7-22.

8. Beamish, P. W. (1993), "The Characteristics of joint ventures in the People's Republic of China", Journal of International Marketing, Vol. 1 No. 2, pp. 29-48.

9. Bruijn, E. and Jia, X. (1993), "Managing Sino-Western joint ventures: product selection strategy", Management International Review, Vol. 33 No 4, pp. 335-360.

10.Campbell, N. (1989), A Strategic Guide to Equity Joint Ventures in China, Pergamon Press.

11.Chan, P. S. (1996), "International joint ventures in East Asia: an exploratory study", American Business Review, Vol. 14 No. 2, pp. 19-23.

12.Chen, B. (1995), "On strategy change of using foreign capital” (in Chinese), Management World, No. 6, pp. 45-48.

13.Chi, T. and McGuire, D. J. (1996), "Collaborative ventures and value of learning: integrating the transaction cost and strategic option perspectives on the choice of market entry modes", Journal of International Business Studies, Vol. 27 No. 2, pp. 285-307.

14. Chua, B. and Kin-Man, G. T. (1993), "Managing joint ventures in China: A crosscultural approach to motivation and quality", International Journal of Management, Vol. 10 No. 3, pp. 294-299.

15. Davies, S. (1994), "China's treasure chest unlocked: assessing the potential for UK businesses hoping to strike gold on the streets of Beijing. Financial Times, 20th May, p.12.

16. Fan, Y. (1996), "Research on joint ventures in China: progress and prognosis", Journal of Euromarketing, Vol. 4 No. 3, 3/4, pp. 71-89.

17. Fey, C. F. (1994), "International joint ventures: an important topic for the 1990s and beyond", Working Paper, Western Business School, The University of Western Ontario, London, Ontario. 
18. Friedman, W. and Kalmanoff, G. (1961), Joint International Business Ventures, Columbia University Press, New York.

19. Glaister, K. W. and Wang, Y. (1993), "UK joint ventures in China: motivation and partner selection", Marketing Intelligence and Planning, Vol. 11 No. 2, pp. 9-15.

20. Hamel, G. (1991), "Competition for competence and inter-partner learning within international strategic alliances", Strategic Management Journal, Vol. 12 (special issue), pp. 83-103.

21. Han F. and Xu Y. (1995), "Ample analysis of the management situation of Sino-foreign co-operated enterprises and the study of countermeasure" (in Chinese), Management World, No. 6, pp. 140-150.

22. Harrigan, K. R. (1986), Managing for Joint Venture Success, Lexington Books, D. C. Health and Company, Massachusetts, USA.

23. Hennart, J. (1988), "The transaction cost theory of equity joint ventures", Strategic Management Journal, Vol. 9, pp. 361-374.

24. Hennart, J. (1991), "The transaction cost theory of joint ventures: an empirical study of Japanese subsidiaries in the United States", Management Science, Vol. 37 No. 4, pp. 483497.

25. Janger, A. (1980), Organization of International Joint Ventures, the Conference Board, New York.

26. Killing, P. (1983), Strategies for Joint Ventures Success, Pager, New York.

27. Lan, P. (1996), "Role of IJVs in transferring technology to China", Journal of Euromarketing, Vol. 4 No. 3-4, pp. 129-153.

28. Lerner, M. (1996), "Cystine and Cysterine recovering after period of uncertain supply", Chemical Market Reporter, Vol. 250 No. 23, p. 14.

29.Lu, M. (1997), "Regional allocation of foreign direct investment and appraisal of China's investment environment" (in Chinese), Economic Research Journal, No. 12, pp. 37-44.

30. Lu, X. (1996), "What are the multinational companies bring to our management", (in Chinese), Economic Theory and Business Management, No. 5, pp. 34-36.

31. Lu Y. and Wang X. (1996), "Strategy and practice of international companies in China" (in Chinese). Management World, No. 2, pp. 139-150.

32. Luo, Y. (1995), "Business strategy, market structure, and performance of international joint ventures: the case of joint ventures in China", Management International Review, Vol. 35 No. 3, pp. 241-264.

33. Martinsons, M. G. and Tseng, C. S. (1995a), "Successful joint ventures in the heart of the dragon”, Long Range Planning, Vol. 28 No. 5, pp. 45-58.

34. Martinsons, M. G. and Tseng, C. S. (1995b), "High-technology management in China: a case study of the Shanghai success stories", Journal of Engineering and Technology Management, Vol. 12, pp. 111-137.

35. Michell, W. and Singh, K. (1996), "Survival of business using collaborative relationships to commercialize complex goods", Strategic Management Journal, Vol. 17 No. 3, pp. 169-195.

36. Miles, M.B. and Huberman, A.M. (1994), Qualitative Date Analysis, Sage Publications, Thousand Oaks, California.

37. Osland, G. E. and Cavusgil, S. T. (1996), "Performance issues in US-China joint ventures", California Management Review, Vol. 38 No. 2 (Winter), pp. 106-130.

38. Pan, Y. (1994), "Features of European equity joint ventures in China: a longitudinal study", Journal of Euromarketing, Vol. 4 No. 1, pp. 5-21. 
39. Pan, Y., Vanhonacker, W. R. and Pitts, R. E. (1995), "International equity joint ventures in China: operations and potential close-down”, Journal of Global Marketing, Vol. 8 No. 3/4, pp. 125-149.

40. Rong, Y. and Wei, D.(1994), The Theory and the Practice: Managing Sino-foreign Joint Ventures in China (in Chinese), FEC Press, Beijing.

41.Schroath, F. W., Hu, M. Y. and Chen, H. (1993), "Country-of-origin effects of foreign investments in the People's Republic of China", Journal of International Business Studies, Vol. 24 No. 2, pp. 277-290.

42. Sweeney, M. (1994), "A methodology for the strategic management of international manufacturing and sourcing”, International Journal of Logistics Management, Vol. 5 No. 1, pp. 55-65.

43. Teagarden, M. B. and Glinow, M. A. V. (1990), "Sino-foreign strategic alliance types and related operating characteristics", International Studies of Management \& Organization, Vol. 20 No. 1-2, pp. 99-108.

44. Tsang, E. W. K. (1994), "Human resource management problems in Sino-foreign joint ventures", International Journal of Manpower, Vol. 15 No. 9, pp. 4-21.

45. Tsang, E. W. K. (1995), "The implementation of technology transfer in Sino-foreign joint ventures", International Journal of Technology Management, Vol. 10 No. 7-8, pp. 757766.

46. Wang, Z. (1996), "Positive and negative influences of investment by international companies on China's economy" (in Chinese). Management World, No. 3, pp. 67-78.

47. Yan A. and Gray, B. (1994), "Bargaining power, management control, and performance in United States-China joint ventures: a comparative case study", Academy of Management Journal, Vol. 37 No. 6, pp. 1478-1517.

48. Zhang, L. and Goffin, K. (1998) "Joint Venture Manufacturing in China-Key Opportunities for Operations Management Research", Cranfield School of Management Working Paper SWP 1/98. 
Table I: Background Information and Cross-Case Analysis of the Six Manufacturing IJVs in China

\begin{tabular}{|c|c|c|c|c|c|c|}
\hline Company & Coating-Co & Brake-Co & Digi-Switch-Co & Boiler-Co & Motor-Co & Fridge-Co \\
\hline \multicolumn{7}{|c|}{ Background Information } \\
\hline Industry & Chemicals & Automotive supply & Electronics & Energy & Automotive & Electrical appliances \\
\hline Product & Protective Coatings & Car Disc Brakes & $\begin{array}{l}\text { Digital Switches for } \\
\text { Telephone Exchanges }\end{array}$ & $\begin{array}{l}\text { Steam Boilers for Power } \\
\text { Generation }\end{array}$ & $\begin{array}{l}\text { Motorcycles for Family } \\
\text { Transportation }\end{array}$ & $\begin{array}{l}\text { Refrigerators for } \\
\text { Consumer Use }\end{array}$ \\
\hline No. of Employees & 240 & 58 & 1,400 & 3,000 & 1,000 & 1,000 \\
\hline History (contract) & $1990-2014$ & $1994-2042$ & $1988-2010$ & $1986-2036$ & 1994-2024 & $1995-2025$ \\
\hline Location & Coastal Area & Coastal Area & Metropolitan & Metropolitan & Inland & Inland \\
\hline Total Investment & $\$ 15.6 \mathrm{~m}$ & $\$ 33 \mathrm{~m}$ & $\$ 82.6 \mathrm{~m}$ & $\$ 24 \mathrm{~m}$ & $\$ 52 \mathrm{~m}$ & $\$ 40 \mathrm{~m}$ \\
\hline Ownership & $51 \% \mathrm{UK} ; 49 \% \mathrm{CN}$ & $20 \%$ UK; $40 \% \mathrm{CN} ; 40 \% \mathrm{KR}$ & $40 \% \mathrm{D} ; 60 \% \mathrm{CN}$ & $50 \%$ US; $50 \% \mathrm{CN}$ & $50 \% \mathrm{~J} ; 50 \% \mathrm{CN}$ & $60 \% \mathrm{~S} ; 40 \% \mathrm{CN}$ \\
\hline $\begin{array}{l}\text { Manufacturing } \\
\text { Characteristics }\end{array}$ & $\begin{array}{l}\text { Make-to-Stock \&-to-Order; } \\
\text { MRP-II based }\end{array}$ & $\begin{array}{l}\text { Make-to-Stock; } \\
\text { MRP-II based }\end{array}$ & $\begin{array}{l}\text { Make, Assembly-to-Order } \\
\text { MRP-II }\end{array}$ & $\begin{array}{l}\text { Make-to-Order; } \\
\text { Project Management }\end{array}$ & $\begin{array}{l}\text { Make-to-Stock; } \\
\text { JIT+MRP-II (CIM) }\end{array}$ & $\begin{array}{l}\text { Make-to-Stock; } \\
\text { MRP-II based }\end{array}$ \\
\hline Performance & Profit making & $\begin{array}{l}\text { Not known (full production } \\
\text { yet to start) }\end{array}$ & Profit making & Profit making & Profit making & Loss making \\
\hline Interviewees & $\begin{array}{ll}\text { - } & \text { British Manager of } \\
\text { Business Development } \\
\text { (Interviewed in UK) } \\
\text { - } \\
\text { Telephone discussions } \\
\text { with admin. manager } \\
\end{array}$ & $\begin{array}{ll}\text { British Director of } \\
\text { Business Development } \\
\text { (interviewed in UK) }\end{array}$ & $\begin{array}{ll}\text { - } & \text { Chinese Manager of } \\
\text { Production Division } \\
\text { (interviewed in China) }\end{array}$ & $\begin{array}{ll}\text { Chinese Manager of } \\
\text { Purchasing Division } \\
\text { (interviewed in China) }\end{array}$ & $\begin{array}{ll}\text { - } & \text { Chinese General } \\
\text { Operating Manager } \\
\text { (interviewed in China) } \\
\text { - } & \text { Short discussions with } \\
\text { administration manager }\end{array}$ & $\begin{array}{ll}\text { - } & \text { Swedish Operating } \\
\text { Director (interviewed } \\
\text { in China) } \\
\text { - } & \text { Short discussion with } \\
& \text { Personnel Manager } \\
\end{array}$ \\
\hline \multicolumn{7}{|c|}{ Cross-Case Analysis } \\
\hline $\begin{array}{l}\text { 1. Recruitment } \\
\text { and Training }\end{array}$ & $\begin{array}{l}\text { - Recruiting and training } \\
\text { local people }\end{array}$ & $\begin{array}{ll}\text { - } & \text { Recruitment of good } \\
\text { people }\end{array}$ & $\begin{array}{ll}\text { - Not enough qualified } \\
\text { personnel for operations }\end{array}$ & $\begin{array}{l}\text { Training and retaining } \\
\text { managers at mid-level }\end{array}$ & $\begin{array}{l}\text { - Training people to work } \\
\text { to international standard }\end{array}$ & $\begin{array}{l}\text { - Middle managers } \\
\text { and professionals } \\
\end{array}$ \\
\hline $\begin{array}{l}\text { 2. Supplier } \\
\text { management }\end{array}$ & - $\quad$ Sourcing local supply & $\begin{array}{l}\text { - Organizing the supply } \\
\text { base }\end{array}$ & $\begin{array}{l}\text { - Managing the } \\
\text { performance of suppliers }\end{array}$ & $\begin{array}{l}\text { - Quality of key materials } \\
\& \text { components }\end{array}$ & $\begin{array}{ll}\text { - } & \text { Supplier development } \\
\text { strategy \& performance }\end{array}$ & $\begin{array}{l}\text { - Uneven quality from } \\
\text { suppliers }\end{array}$ \\
\hline $\begin{array}{l}\text { 3. Quality } \\
\text { management }\end{array}$ & $\begin{array}{ll}- & \text { Maintaining quality } \\
\text { standards } \\
\text { - } & \text { Need for regular } \\
\text { training }\end{array}$ & $\begin{array}{ll} & \text { Need for training } \\
- & \text { Problems achieving } \\
& \text { customer service levels }\end{array}$ & $\begin{array}{ll} & \text { Quality education } \\
\text { - } & \text { Strict inspections } \\
& \text { required }\end{array}$ & $\begin{array}{ll}- & \text { Extensive focus on } \\
& \text { quality (visits to Japan) } \\
- & \text { Delivery problems } \\
\text { - } & \text { Strict inspections } \\
\end{array}$ & $\begin{array}{ll}- & \text { Manufacturing control } \\
\text { purchasing \& marketing } \\
\text { - } & \text { Incoming and other } \\
\text { quality inspections }\end{array}$ & $\begin{array}{ll}\text { - } & \text { Quality problems in } \\
\text { manufacturing and } \\
\text { after-sales service } \\
\text { - } & \text { Training equirements } \\
\end{array}$ \\
\hline $\begin{array}{l}\text { 4. Achieving an } \\
\text { effective IJV } \\
\text { business culture }\end{array}$ & $\begin{array}{l}\text { Understanding of how } \\
\text { modern business works } \\
\text { Being patient to local } \\
\text { people, understanding } \\
\text { the local culture }\end{array}$ & $\begin{array}{l}\text { - Keeping international } \\
\text { operations up to } \\
\text { standards }\end{array}$ & $\begin{array}{l}\text { Getting staff understand } \\
\text { each other at all levels } \\
\text { - Getting people to accept } \\
\text { Western working model }\end{array}$ & $\begin{array}{ll}\text { - } & \text { Project management } \\
\text { Disputes between } \\
\text { partners }\end{array}$ & - Order management & $\begin{array}{ll}\text { - } & \text { Keeping people } \\
& \text { working as one team } \\
\text { - } & \text { Merging different } \\
\text { styles }\end{array}$ \\
\hline $\begin{array}{l}\text { 5. Other } \\
\text { operations issues }\end{array}$ & $\begin{array}{ll} & \text { Choosing right partner } \\
\text { - } & \text { Building a chemical } \\
& \text { plant to safety levels } \\
\end{array}$ & - $\quad$ Delivery of plant & & $\begin{array}{ll} & \text { Cash flow problems } \\
- & \text { Reducing purchasing \& } \\
& \text { manufacturing costs } \\
\end{array}$ & & $\begin{array}{ll} & \text { Reducing total cost } \\
- & \begin{array}{l}\text { Developing new } \\
\text { products }\end{array} \\
\end{array}$ \\
\hline
\end{tabular}

